Germany to build eight 1000 Megawatt nuclear plants in Brazil. Daniel Ludwig, an American citizen, owns a land area the size of Switzerland at the confluence of the river Jari and the Amazon. Investments in homogeneous forest plantation, a cellulose factory, cattle raising and rice growing on this site amount to $\$ 700$ million, and will reach $\$ 1.5$ billion in a few years when a paper factory is completed.

Banners reading "Amazonia is ours" were spread around an overflowing amphitheatre as Charles Briscoe, the American technician in charge of the Jari Project, explained that "Project Jari covers more than one million hectares in the State of Pará and the Federal Territory of Amapá . . . There are no boats loaded with gold or other riches leaving the country."' But critics pointed out that all of Jari's activities are geared exclusively for export, and that the appropriateness of their technology is never considered. Agricultural production, for example, is fully industrilized: rice is sown by plane and tree planting and cutting are fully mechanized. Parts of Briscoe's presentation met with boos from the participants, several of whom denounced foreign control and the elimination of the indigenous Indian population.

\section{West German nuclear deal heavily criticised}

The government's nuclear programme was strongly criticised by Brazilian physicists on economic and political grounds; the technical and environmental arguments which dominate the nuclear debate in industrialised countries were not brought up. Professor Luis Pinguelli Rosa of the Federal University of Rio de Janeiro proposed a drastic revision of the contract with West Germany. He claimed that Brazil is in a position of strength: "Germany presently does not have other clients for its reactors. The only reason we did not succeed in imposing our conditions is because we owe $\$ 40$ billion to the industrialised world, and that forces us to follow a policy which is perfect for our creditors but not for ourselves." $\mathrm{He}$ also indicated that an official report by the Ministry of Planning recognises that the cost of electrical energy produced by nuclear reactors is three times that from hydroelectric schemes.

A longer-term view was presented by Professor Mario Schemberg, who trained some of the best known Brazilian physicists before he was forcibly ietired from the University of Sao Paulo by the military government in 1969. He made an appeal for "freeing ourselves from the useless weight of the nuclear agreement with Germany, and cancelling the pledges which the military dictatorship made without consulting the people." He proposed an energy programme for Brazil for the next fifty years which would emphasise research in solar energy and nuclear fusion.

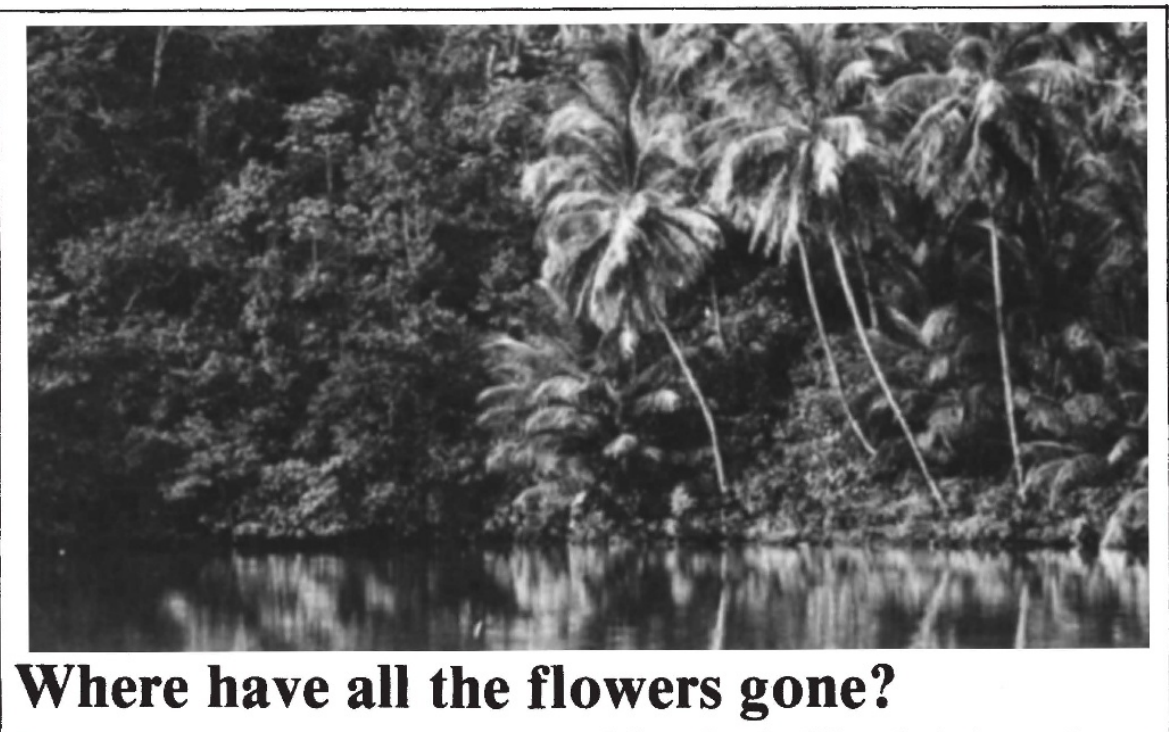

THE savage destruction of the Brazilian rain forests has been dictated, to a large extent, by economic pressures over which the country's government can exercise little control. Yet this rapidly dwindling heritage of exotic plants and animals kindled the imagination of early explorers and continues to contribute to our understanding of our natural environment. In Brazil today the cultural and economic influence of the West is very apparent, and so it is strange to find little native interest in natural history reflected on the shelves of the big bookshops of cities such as Rio de Janeiro, Brasilia and Belo Horizonte. Despite a good deal of enquiry the only books I could find dealing with Brazilian wildlife at all were translations of glossy foreign 'coffee table' volumes.

Long searches through the second-hand markets uncovered only four more: a series published in Säo Paulo in the 1950s dealing with insects, birds and mammals; and a magnificent translation of an illustrated French book on Amazonian primates, published at the turn of the century whose value was, unfortunately, well appreciated by the dealer. The Brazilian flora suffer a similar neglect, even though, at certain times of the year, one would be well advised to take some sort of field guide along when visiting the local fruit and vegetable markets.

Being able to name and classify species of plant and animal is an essential cornerstone of biological science and education. Once these basic elements can be identified, and their interactions understood, one may begin to appreciate the fragility of eco-systems such as the tropical rain forest.

It is disturbing, therefore, to find that wouldbe medical students, when asked to give the names of all the animal species they knew, could list, on average, only half a dozen - invariably creatures of medical importance such as the mosquito, the cockroach and the 'barbeiro', the bug vector of Chagas disease. Although this survey carried out by Professor Angelo Machado of the Federal University of
Minas Gerais, did not include questions on plant life, my own experiences suggested that here the situation is even worse. Indeed, one graduate biologist I spoke to was surprised to discover that naturaI selection occurs outside the animal kingdom!

Machado is a well respected morphologist and neuroanatomist, whose spare time pursuits include some most elegant studies on the ecology and taxonomy of neo-tropical dragonflies. His wide interests include conservation - he is a founder member of one of the few environmental pressure groups in the country - and, more recently, an attempt to understand the lack of interest in wildlife which is apparent in the country's development of its natural resources. Brazil's politicians and administrators, he feels, are 'frightened by nature', and so he has turned to studying the development of the concept of the 'forest' in school children throughout the country.

This survey is still in its early stages, but Machado has already found that the child's concept of the forest, and its association with fear, begins to form early in life. It seems to be based on nursery rhymes and children's stories imported from Europe and North America, which emphasise the dangers of going into the woods.

In the younger child this ignorance can be easily counteracted. Drawings and paintings of the 'forest' made by 7-10 year olds commonly included aeroplanes spraying the undergrowth with bullets and napalm; but after the same children had been taken by Machado on a trip to the real forest these were replaced by birds and butterflies, and the children paid far more artistic attention to leaf forms and flowers.

At the present rate of development Brazil's forests may only survive for another 30 years, but if Machado's children can be so easily convinced of its value there is some hope that this new generation may allow it to stand for longer. The final decision may perhaps lie with the teachers rather than the politicians.

David Bousfield 